\title{
Yield and Quality Evaluation of Direct Seeded Basmati Rice (Oryza sativa L.) under Different Irrigation and Nitrogen Regimes
}

\author{
J. KAUR ${ }^{1 *}$, S.S. MAHAL ${ }^{1}$ and A. KAUR ${ }^{2}$ \\ ${ }^{1}$ Department of Agronomy, Punjab Agricultural University, Ludhiana, Punjab, India \\ ${ }^{2}$ Department of Food Science and Technology, Punjab Agricultural University, Ludhiana, Punjab, India
}

(Received 27 May 2015; Accepted 29 July 2015;

Communicated by J. Kubát)

\begin{abstract}
Management practices need to be developed for successful cultivation of good quality aerobic basmati rice. Field experiments were conducted at Ludhiana, India during the summer seasons of 2011 and 2012 to ascertain the optimum irrigation schedule and dose and timings of nitrogen application to direct seeded basmati rice cultivar Pusa Basmati 1121. Three irrigation schedules (irrigations at 30,50 and $70 \mathrm{~mm} \mathrm{CPE),} \mathrm{three} \mathrm{nitrogen} \mathrm{levels} \mathrm{(40,}$ 60 and $\left.80 \mathrm{~kg} \mathrm{~N} \mathrm{ha}^{-1}\right)$ and two modules of nitrogen splits (3 splits, i.e. application at 3, 6 and 9 weeks after sowing and 4 splits, i.e. application at $0,3,6$ and 9 weeks after sowing) were tested in randomized block design with four replications on a loamy sand soil. The maximum grain yield, protein content, brown, milled and head rice recovery were obtained with irrigations at $30 \mathrm{~mm} \mathrm{CPE}$ and these were significantly better than 50 and $70 \mathrm{~mm}$ CPE irrigation schedules. Among nitrogen levels, the significant increase in grain yield as well as quality parameters, viz. protein content, brown, milled and head rice recovery was recorded only up to a nitrogen dose of $60 \mathrm{~kg} \mathrm{ha}^{-1}$. In Indian Punjab, good quality direct seeded basmati rice can be produced by following the irrigation schedule of $30 \mathrm{~mm} \mathrm{CPE}$ and with the application of $60 \mathrm{~kg} \mathrm{~N} \mathrm{ha}^{-1}$ applied in 3 splits (3, 6 and 9 weeks after sowing).
\end{abstract}

Keywords: aerobic rice, milling and cooking quality, hectolitre weight, $\mathrm{N}$ splits

\section{Introduction}

Rice (Oryza sativa L.), being the most important cultivated plant with respect to consumption by humans, accounts for $35-75 \%$ of the calorie intake of more than 3 billion humans. With the likely growth of world's population toward 10 billion by 2050, the demand for rice will grow faster than for other crops. Thus, rice holds the key for food security and prosperity. But there are many challenges for achieving higher productivity of rice. Since the per capita availability of water used in agriculture is declining day by day and the situation is even more worst in the northwest Indo-Gangetic Plains (IGP) of India where underground water is not utilized judiciously and water table is declining at an alarming rate. Because of dual problems of increasing constraints of labour and water

\footnotetext{
*Corresponding author; E-mail: jagmohanpau3@gmail.com
} 
availability, direct seeded rice (DSR) is now considered to be a new and emerging rice production system. Punjab farmers have shown keen interest in cultivation of direct seeded rice especially cultivar Pusa Basmati 1121.

Proper water management is imperative for getting high yields of good quality DSR as the occurrence of soil moisture stress affects many of the physiological processes such as photosynthesis and transpiration resulting in reduced growth and poor grain filling (Samonte et al. 2001). Also, nitrogen is the most limiting nutrient for crop production and its efficient management is critical in yield realization of irrigated rice ecosystem. The dynamic nature of $\mathrm{N}$ and its propensity for loss from soil-plant systems makes its management more difficult. Land preparation and water management are the principal factors governing the nutrient dynamics in rice cultivation. Synchrony of N supply with crop demand is essential in order to ensure optimum yield. Split applications more closely match uptake patterns than single large pre-season application and reduce loss and increase nitrogen use efficiency (De Datta 1986).

In countries, where rice is consumed, traits of grain quality dictate market value of any variety. Rice quality is a multi-faceted trait. Among various quality parameters, nutritional value and milling deserve more attention since these determine the market acceptability. Genetic, environmental and agronomical factors play an important role in determining composition and cooking quality of rice.

The irrigation and nitrogen are the key inputs in determination of the quality of rice. Very limited research has been done on optimizing irrigation and nutrient management in direct seeded culture in Northwest Indo-Gangetic Plains and also a little information is available about their effect on the quality parameters of direct seeded basmati rice. Therefore, the objective of present study was to evaluate and identify irrigation and $\mathrm{N}$ management practices for enhancing the performance of direct seeded basmati rice in terms of yield and quality.

\section{Materials and Methods}

\section{Experimental site and soil characteristics}

Field experiments were conducted at Punjab Agricultural University, Ludhiana, (30 $56^{\circ}$ $\mathrm{N}, 75^{\circ} 52^{\prime} \mathrm{E}$ and $247 \mathrm{~m}$ above sea level), Punjab, India, during the summer seasons of 2011 and 2012 to ascertain the possible irrigation and nitrogen management practices to enhance the productivity of direct seeded basmati rice cultivar Pusa Basmati 1121. The climate of the area is subtropical with a hot summer, wet monsoon season (July-September) and a cool dry winter. Average annual rainfall is $734 \mathrm{~mm}, 85$ per cent of which falls during the monsoon season. The soil of the experimental site was loamy sand with $\mathrm{pH}$ 7.6, electrical conductivity $0.16 \mathrm{dS} \mathrm{m}^{-1}$, organic carbon $0.42 \%$, available $\mathrm{N} 280.27 \mathrm{~kg}$ $\mathrm{ha}^{-1}$, available P $21.65 \mathrm{~kg} \mathrm{ha}^{-1}$ and available K $210.29 \mathrm{~kg} \mathrm{ha}^{-1}$. 


\section{Experimental design, sowing, fertilizer and irrigation scheduling}

Three irrigation schedules, viz. irrigation of $7.5 \mathrm{~cm}$ on occurrence of 30,50 and $70 \mathrm{~mm}$ cumulative pan evaporation (CPE), three nitrogen levels, viz. 40,60 and $80 \mathrm{~kg} \mathrm{~N} \mathrm{ha}^{-1}$ and two nitrogen splits, viz. 3 equal splits, i.e. application at 3, 6 and 9 weeks after sowing and 4 equal splits, i.e. application at $0,3,6$ and 9 weeks after sowing, were laid out in a randomized block design in four replications. Rice was grown in the same plots (gross size of $18 \mathrm{~m}^{2}$ ) with net plot size of $10 \mathrm{~m}^{2}$ during both the years. Each plot was surrounded by a buffer of $0.75 \mathrm{~m}$ width. Sowing was done on $24^{\text {th }}$ June during both the years using a seed rate of $25 \mathrm{~kg} \mathrm{ha}^{-1}$. Seed was placed at a depth of $2.5 \mathrm{~cm}$ using single row drill. The row to row spacing was $20 \mathrm{~cm}$. The recommended dose of phosphorus $\left(30 \mathrm{~kg} \mathrm{P}_{2} \mathrm{O}_{5} \mathrm{ha}^{-1}\right)$ as single super phosphate, potassium $\left(30 \mathrm{~kg} \mathrm{~K}_{2} \mathrm{O} \mathrm{ha}^{-1}\right)$ as muriate of potash and zinc sulphate heptahydrate $\left(62.5 \mathrm{~kg} \mathrm{ha}^{-1}\right)$ were applied at the time of seedbed preparation by broadcasting. Nitrogenous fertilizer was applied in the form of urea as per the treatments. For controlling weeds, the pre-emergence application of Stomp 30 EC (Pendimethalin) 2.5 litres ha ${ }^{-1}$ was followed by Nominee Gold (Bispyribac 10 SC) on 30 days after sowing $250 \mathrm{ml} \mathrm{ha}^{-1}$ during both the years. The left over weeds were removed by giving hand weeding at around $60 \mathrm{DAS}$, during both years.

Seventy-five $\mathrm{mm}$ depth of irrigation water was applied when the CPE reached a level of 30,50 and $70 \mathrm{~mm}$. Parshall flume was used for measuring the amount of irrigation water. The total number of irrigations applied in 30,50 and $70 \mathrm{~mm}$ CPE irrigation schedules during 2011 were 8,5 and 2, while during 2012 these were 11,7 and 5, respectively. The total rainfall received during the crop season was $963.2 \mathrm{~mm}$ (uneven as $400 \mathrm{~mm}$ received on a single day) and $387 \mathrm{~mm}$ during 2011 and 2012, respectively.

\section{Yield, milling and physicochemical properties}

At harvest, grain yield was measured at 14 per cent moisture content. Milling characteristics (brown, milled and head rice recovery) and other physicochemical properties were evaluated by following the standard protocol of IRRI. The milled whole rice kernels were used for the evaluation of physicochemical and cooking properties. The hectolitre weight $\left(\mathrm{kg}\right.$ hectolitre ${ }^{-1}$ ) was determined by filling a container of one litre capacity. The weight of grains $(\mathrm{kg})$ was recorded in triplicate from every plot, average was determined and it was multiplied with 100 to convert it into Hectolitre weight $\left(\mathrm{kg} \mathrm{hectolitre}^{-1}\right)$. The length and breadth of ten grains were measured before and after cooking of samples and average of length and breadth was taken in mm and grain length/breadth ratio was calculated. Protein and amylose content of milled rice was determined with Zx 800 Near Infrared Grain Analyzer of Zeltex Inc. and the results were expressed as percentage. Amylopectin content in grains were determined by the following formula given by Low (1994). The results were expressed as percentage.

$$
\text { Amylopectin }(\%)=100-\{\text { Moisture }(\%)+\text { Protein }(\%)+\text { Amylose }(\%)+\text { Ash }(\%)\}
$$




\section{Cooking properties}

For determination of minimum cooking time, two grams of head rice sample was taken in $50 \mathrm{ml}$ beaker and cooked with $20 \mathrm{ml}$ of distilled water in boiling water bath. The minimum cooking time was determined by removing a few kernels at different time and pressing them between two glass plates, the procedure of cooking was carried out till no white core was observed between the plates and at this moment, time was noted and the time taken was recorded as minimum cooking time in minutes. Elongation ratio was determined by dividing cumulative length of ten cooked kernels by length of ten uncooked kernels. For the determination of water uptake ratio, two grams of head rice was cooked in $20 \mathrm{ml}$ of distilled water for minimum cooking time in boiling water bath. The contents were drained and weighed. The superficial water was removed by pressing the cooked kernels between the folds of filter paper sheets. The cooked sample was weighed accurately. Water absorption ratio was calculated by dividing weight of cooked grains by weight of raw grain $(2 \mathrm{~g})$.

For determination of gruel solids loss two grams of milled rice was taken in $50 \mathrm{ml}$ beaker, $20 \mathrm{ml}$ of distilled water was added and it was cooked for minimum cooking time in boiling water bath. After cooking, gruel left in the beaker was transferred into $100 \mathrm{ml}$ measuring flask. The cooked rice was washed in distilled water to remove the traces of the gruel. Distilled water was added to make the volume $100 \mathrm{ml}$. Ten $\mathrm{ml}$ of diluted gruel from the measuring flask was transferred to a Petri dish in duplicate. Petri dishes were placed in an oven at $100{ }^{\circ} \mathrm{C}$ and dried till constant weight. The weight of solids left in the Petri dishes was determined. The gruel solids loss was calculated by the formula given below and expressed in percentage:

$$
\text { Gruel solids loss }(\%)=\frac{\text { Weight of solids left in Petri dish }(\mathrm{g}) \times 100 \times 100}{10 \times 2}
$$

\section{Statistical analysis}

The data was subjected to statistical scrutiny as per the proceedings of Gomez and Gomez (1984).

\section{Results}

As large variation in rains during the course of study affected the crop greatly, thus the results are being presented years-wise. The total rainfall received during the crop season was $379.1 \mathrm{~mm}$ above normal $(612.3 \mathrm{~mm})$ for basmati growing season and $223.3 \mathrm{~mm}$ below the normal during 2011 and 2012, respectively. The average relative humidity was 13.84 per cent higher in 2011 as compared to the normal (67.48 per cent) and in 2012, it was 2.9 per cent higher than the normal average relative humidity during the growing season. Thus, overall the weather was more congenial for basmati during the year 2012 . 


\section{Crop performance}

\section{Yield}

As depicted in Table 1, the maximum grain yield (33.6 and $43.1 \mathrm{q} \mathrm{ha}^{-1}$ ) was obtained in irrigation schedule of $30 \mathrm{~mm} \mathrm{CPE}$ and it was significantly better than that obtained in 50 $\mathrm{mm}$ (28.1 and $36.8 \mathrm{q} \mathrm{ha}^{-1}$ ) and $70 \mathrm{~mm} \mathrm{CPE} \mathrm{(18.7} \mathrm{and} 26.5 \mathrm{q} \mathrm{ha}^{-1}$ ) irrigation schedules, during 2011 and 2012, respectively. In case of nitrogen levels, although the grain yield was maximum in $80 \mathrm{~kg} \mathrm{~N}^{-1}$ but was statistically similar to that obtained with $60 \mathrm{~kg} \mathrm{~N}$ $\mathrm{ha}^{-1}$ and significantly higher than $40 \mathrm{~kg} \mathrm{~N} \mathrm{ha}^{-1}$ during both the years of study. The per cent increase in yield by 80 and $60 \mathrm{~kg} \mathrm{~N}^{-1}$ over $40 \mathrm{~kg} \mathrm{~N}^{-1}$ was 20.3 and 13.7 during 2011 and 17.6 and 11.8 during 2012, respectively. Application of nitrogen in either 3 or 4 splits did not affect the yield. The interaction effect of irrigation schedules, nitrogen levels and its splits was found to be statistically non-significant.

\section{Quality characters of basmati rice}

\section{Milling quality and physical properties of paddy}

The maximum brown, milled and head rice recovery was observed in grains obtained from irrigation schedule of $30 \mathrm{~mm}$ CPE which was significantly higher than 50 and 70 mm irrigation schedules (Table 1). During both the years, brown, milled and head rice

Table 1. Effect of different irrigation schedules, nitrogen levels and nitrogen splits on grain yield and milling quality of direct seeded basmati rice (expressed as percentage of paddy)

\begin{tabular}{|c|c|c|c|c|c|c|c|c|}
\hline \multirow{2}{*}{ Treatments } & \multicolumn{2}{|c|}{ Grain yield $\left(\mathrm{q}\right.$ ha $\left.^{-1}\right)$} & \multicolumn{2}{|c|}{ Brown rice recovery $(\%)$} & \multicolumn{2}{|c|}{ Milled rice recovery $(\%)$} & \multicolumn{2}{|c|}{ Head rice recovery $(\%)$} \\
\hline & 2011 & 2012 & 2011 & 2012 & 2011 & 2012 & 2011 & 2012 \\
\hline \multicolumn{9}{|c|}{ Irrigation schedules } \\
\hline $30 \mathrm{~mm} \mathrm{CPE}$ & 33.6 & 43.1 & 78.3 & 79.4 & 67.4 & 70.3 & 50.6 & 52.1 \\
\hline $50 \mathrm{~mm} \mathrm{CPE}$ & 28.1 & 36.8 & 77.2 & 77.9 & 65.7 & 68.5 & 47.3 & 48.2 \\
\hline $70 \mathrm{~mm} \mathrm{CPE}$ & 18.7 & 26.5 & 76.0 & 76.3 & 64.1 & 67.0 & 42.0 & 43.7 \\
\hline L.S.D. $(p=0.05)$ & 1.7 & 2.6 & 1.1 & 1.1 & 1.3 & 1.4 & 3.3 & 2.6 \\
\hline \multicolumn{9}{|c|}{ Nitrogen levels $\left(\mathrm{kg} \mathrm{ha}^{-1}\right)$} \\
\hline 40 & 24.1 & 32.3 & 76.2 & 76.9 & 64.0 & 67.3 & 43.8 & 45.5 \\
\hline 60 & 27.4 & 36.1 & 77.5 & 78.1 & 66.1 & 68.7 & 47.1 & 48.4 \\
\hline 80 & 29.0 & 38.0 & 77.9 & 78.5 & 67.1 & 69.8 & 49.0 & 50.1 \\
\hline L.S.D. $(p=0.05)$ & 1.7 & 2.6 & 1.1 & 1.1 & 1.3 & 1.4 & 3.3 & 2.6 \\
\hline \multicolumn{9}{|c|}{ Nitrogen splits } \\
\hline 3 splits & 26.9 & 35.5 & 77.3 & 77.9 & 65.8 & 68.5 & 46.9 & 48.1 \\
\hline 4 splits & 26.7 & 35.4 & 77.1 & 77.8 & 65.7 & 68.4 & 46.4 & 47.9 \\
\hline L.S.D. $(p=0.05)$ & NS & NS & NS & NS & NS & NS & NS & NS \\
\hline
\end{tabular}

NS: non-significant. 


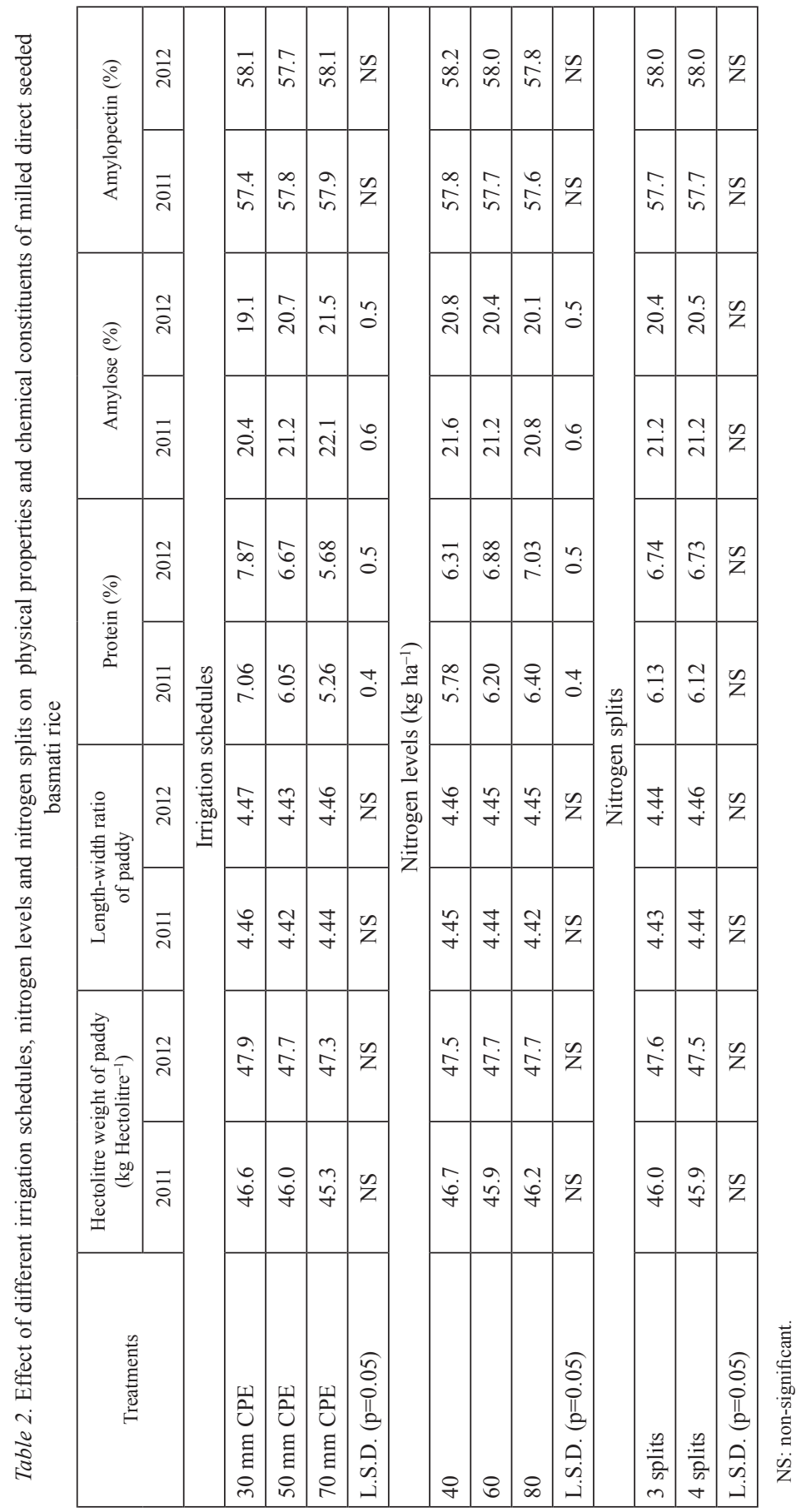


recovery increased significantly up to $60 \mathrm{~kg} \mathrm{~N} \mathrm{ha}^{-1}$ and the further increase to $80 \mathrm{~kg} \mathrm{~N}$ $\mathrm{ha}^{-1}$ was found to be statistically non-significant. Application of nitrogen in either 3 or 4 splits did not influence brown, milled or head rice recoveries.

Irrigation schedules, nitrogen levels and their splits failed to cause any significant change in the hectolitre weight of paddy $\left(\mathrm{kg}\right.$ hectolitre $\left.^{-1}\right)$ as well as length/width ratio of paddy during both the years of study (Table 2).

\section{Chemical constituents of milled rice}

The protein content was significantly influenced by different irrigation schedules during both the years (Table 2). Maximum protein content in milled rice (20.4 and 19.1 per cent, during 2011 and 2012, respectively) was found in $30 \mathrm{~mm} \mathrm{CPE}$ irrigation schedule which was significantly higher than 50 and $70 \mathrm{~mm}$ CPE irrigation schedules. In contrary to this irrigation schedule of $30 \mathrm{~mm} \mathrm{CPE}$, resulted in the lowest value of amylose content of the milled rice which was significantly lower than both of 50 and $70 \mathrm{~mm} \mathrm{CPE}$ irrigation schedules.

Protein content in grains increased with increase in nitrogen levels and the highest protein content was recorded with $80 \mathrm{~kg} \mathrm{~N} \mathrm{ha}^{-1}$ but the increase was significant only up to $60 \mathrm{~kg} \mathrm{~N} \mathrm{ha}^{-1}$ (Table 2). Increase in the protein content by $80 \mathrm{~kg} \mathrm{~N} \mathrm{ha}^{-1}$ over 40 and 60 $\mathrm{kg} \mathrm{N} \mathrm{Na}^{-1}$ was 10.7 and 3.2 per cent, respectively, during 2011 and the corresponding values for 2012 were 11.4 and 2.18 per cent. In contrary to this, highest amylose content was manifested in $40 \mathrm{~kg} \mathrm{~N} \mathrm{ha}^{-1}$ (21.6 and 20.8 per cent) which was statistically similar to that produced by $60 \mathrm{~kg} \mathrm{~N}^{-1}$ (21.2 and 20.4 per cent) and significantly higher than that produced by $80 \mathrm{~kg} \mathrm{~N} \mathrm{ha}^{-1}$ (20.8 and 20.1 per cent) during 2011 and 2012, respectively. Nitrogen splits had non-significant influence on protein and amylose content. Also, none of the interactions were significant. The amylopectin content of milled rice varied nonsignificantly among different irrigation schedules, nitrogen levels as well as its splits during both the years of study (Table 2).

\section{Cooking quality}

Rice produced in the plots irrigated at $30 \mathrm{~mm} \mathrm{CPE}$ took maximum time for cooking and it was significantly higher than 50 and $70 \mathrm{~mm} \mathrm{CPE} \mathrm{irrigation} \mathrm{schedules} \mathrm{(Table} \mathrm{3).} \mathrm{Rice}$ produced in the plots with irrigations at $30 \mathrm{~mm}$ CPE required 8.5 and 16.2 per cent more cooking time than plots with irrigations at 50 and $70 \mathrm{~mm} \mathrm{CPE} \mathrm{during} \mathrm{the} \mathrm{first} \mathrm{year} \mathrm{while}$ during the second year the corresponding increase was 7.3 and 17.0 per cent. Among different irrigation schedules, maximum elongation ratio (1.81 and 1.86, during 2011 and 2012 , respectively) was observed in rice produced by irrigations at $30 \mathrm{~mm}$ CPE. Each increment in the successive irrigation level, significantly lowered the values of elongation ratio. Irrigation schedule of $70 \mathrm{~mm}$ CPE produced maximum gruel solids loss and it was significantly higher than 30 and $50 \mathrm{~mm}$ CPE irrigation schedules.

Among nitrogen levels minimum cooking time increased significantly up to $60 \mathrm{~kg} \mathrm{~N}$ $\mathrm{ha}^{-1}$ and further increase with $80 \mathrm{~kg} \mathrm{~N} \mathrm{ha}^{-1}$ was found to be statistically non-significant 


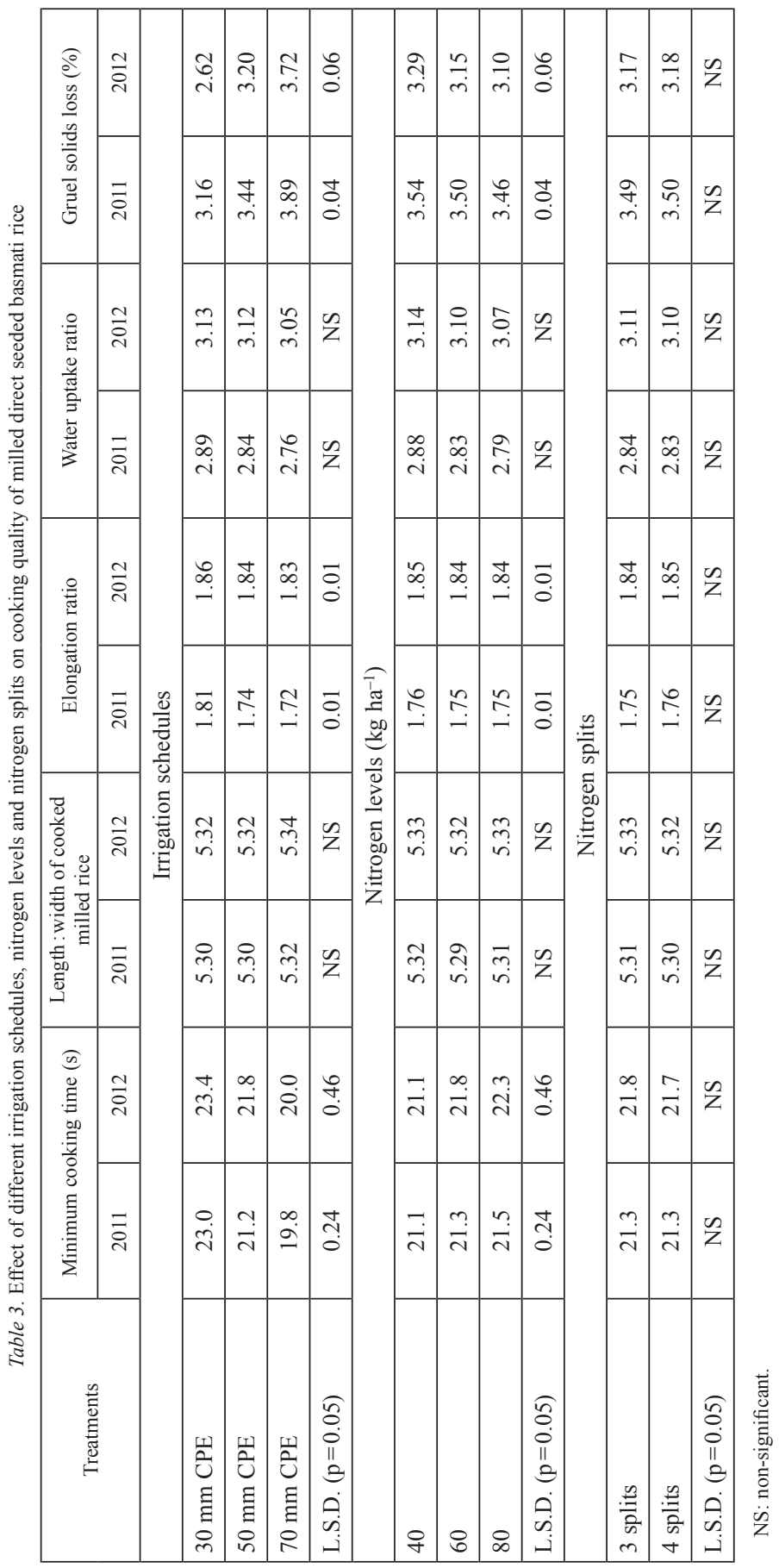

Cereal Research Communications 44, 2016 
during both the years of study (Table 3 ). The numerical range of cooking time varied from 21.1 to 21.5 and 21.1 to 22.3 minutes, during 2011 and 2012, respectively. Increment of nitrogen from 40 to $60 \mathrm{~kg} \mathrm{ha}^{-1}$ decreased the elongation ratio significantly, but further increase to $80 \mathrm{~kg} \mathrm{~N} \mathrm{ha}^{-1}$ failed to influence it. Maximum gruel solids loss of 3.54 and 3.29 per cent was recorded in $40 \mathrm{~kg} \mathrm{~N} \mathrm{ha}^{-1}$, which was significantly higher than 60 and $80 \mathrm{~kg}$ $\mathrm{N} \mathrm{ha}^{-1}$.

Irrigation schedules, nitrogen levels or splits failed to cause significant change in the length: width of cooked milled rice and water uptake ratio. It was found during the study period of two years that rice produced by both the three or four nitrogen splits took statistically similar minimum time for cooking, elongation ratio and gruel solids loss. The interaction effects were statistically non-significant, during both the years of study (Table 3).

\section{Discussion}

The maximum value of yield in $30 \mathrm{~mm}$ CPE irrigation schedule might be due to the favourable edaphic conditions due to adequate moisture in the root zone which enhanced the uptake of nutrients and thus better plant growth and translocation of photosynthates to the grains. Similar results have been reported by Singh et al. (2012). Also, direct seeded basmati crop irrigated at $30 \mathrm{~mm} \mathrm{CPE}\left(39.1 \mathrm{q} \mathrm{ha}^{-1}\right)$ produced statistically at par yield with that of conventional transplanted basmati crop (41.9 $\left.\mathrm{q} \mathrm{ha}^{-1}\right)$ with significantly higher irrigation water productivity of $0.43 \mathrm{~kg} \mathrm{~m}^{-3}$ as compared to transplanted crop $\left(0.31 \mathrm{~kg} \mathrm{~m}^{-3}\right)$ (Kaur and Mahal 2014). Increase in grain yield with increase in nitrogen levels might be attributed to adequate supply of nutrients and metabolites for growth and development of plants (Mahajan et al. 2011). Also, Fageria and Baligar (2001) reported that rice grain yield increased with increased $\mathrm{N}$ supply but up to a certain limit and that a quadratic yield response to $\mathrm{N}$ is considered the most appropriate model in determining $\mathrm{N}$ rate for maximum economic yield.

Huang et al. (2008) reported that as the water stress increased brown and milled rice recovery decreased. Borell et al. (1997) also reported that stress increased proportion of broken grains. Increasing $\mathrm{N}$ levels increased root activity and photosynthetic rate (source supply) during the grain filling, thus would produce and supply more assimilates to the sink organ (grain) and consequently produces higher brown rice per cent due to increased grain size. Increased head rice recovery with higher $\mathrm{N}$ levels might be due to enhanced protein bodies which occupy the space between unpacked starch granules and function as a binder for starch (Leesawatwong et al. 2005). High protein content improves the wholegrain or head rice content (Jongkaewwattana et al. 1993), milled-rice translucency and also high-protein brown rice is more resistant to abrasive milling than low-protein rice of the same variety (Cagampang et al. 1966). Also, protein distribution within the grain becomes more even as protein content increases because the number of protein bodies increase (Juliano et al. 1973).

Protein content in milled rice decreased with increasing moisture stress (Agarwal et al. 1995). This might be due to the increased protease activity which induce breakdown of 
proteins under water stress conditions. The moisture stress increases amylose content of grains. Also, there is negative correlation of amylose and protein content in the rice grains under moisture stress conditions (Fofana et al. 2010). Increase in protein content with increasing levels of nitrogen has also been reported by Kavitha et al. (2008). Nitrogen is an integral part of proteins and its increased application might have resulted in increased nitrogen content in grains, which ultimately increased protein content in milled basmati rice. Fertilizer-N application up to panicle initiation stage is known to increase protein content and possibly grain yield of rice (Juliano et al. 1973). But, increasing nitrogen levels decrease the amylose content (Hao et al. 2007).

Minimum cooking time is closely related with the protein content. It followed the same trend as followed by the protein content in rice produced by different irrigation treatments (Table 3). Also, stressed samples have lower gelatinization temperature and tend to gelatinize quicker (Fofana et al. 2010). It is well known that there is a positive correlation between gelatinization temperature and cooking time (Vidal et al. 2007). The reason for higher elongation ratio in the plots receiving more amount of irrigation water might be attributed to the gelatinization behaviour of carbohydrates among rice grains produced in these plots. The gruel solids loss shows highly significant correlation with amylose content (Singh et al. 2005). Amylose leaches out during cooking and thus the higher amylose content is liable to leach more into the cooking water (Morris 1990). It is also influenced by the L/B ratio of grains (Singh et al. 2011).

The increase in minimum cooking time with increase in nitrogen application might be due to the fact that proteins being harder in nature provide hardness to grain (Leesawatwong et al. 2005) therefore harder grains might have taken more time for cooking. The higher elongation ratio at lower levels of nitrogen may be attributed to higher carbohydrate content among the grains as compared to the grains obtained from plots receiving higher levels of nitrogen. Carbohydrates are responsible for absorption of water, which in turn leads to elongation of rice grains after cooking. Also, gelatinization behaviour of carbohydrates among rice grains varies with nitrogen content. The reason for higher gruel solids loss in $40 \mathrm{~kg} \mathrm{~N} \mathrm{ha}^{-1}$ might be due to the higher amylose content among the grains produced by $40 \mathrm{~kg} \mathrm{~N} \mathrm{ha}^{-1}$. Also, the gruel solids loss is negatively correlated with protein content (Singh et al. 2011).

From the overall appraisal of the study, it can be concluded that good quality and yield in direct seeded basmati rice can be obtained by following the irrigation schedule of 30 $\mathrm{mm}$ CPE and with the application of $60 \mathrm{~kg} \mathrm{~N} \mathrm{ha}^{-1}$ applied in 3 splits (3, 6 and 9 weeks after sowing) in Indian Punjab. In direct seeded basmati rice, the increased $\mathrm{N}$ could not compensate for the yield loss under water stress conditions. It could also be inferred from the results of the study that $\mathrm{N}$ application at sowing time can be skipped because it may not be immediately used by the emerging seedlings. 


\section{References}

Agarwal, G.C., Sidhu, A.S., Singh, N.T. 1995. Effect of the interaction of transplanting rate, irrigation schedule and $\mathrm{N}$ on rice yield. IRRN 14:22-24.

Borell, A., Garside, A., Fukai, S. 1997. Improving efficacy of water use irrigated rice in a semi-arid tropical environment. Field Crops Res. 52:231-248.

Cagampang, G.B., Cruz, L.J., Espiritu, S.G., Santiago, R.G., Juliano, B.O. 1966. Studies on the extraction and composition of rice proteins. Cereal Chem. 43:145-155.

De Datta, S.K. 1986. Improving nitrogen fertilizer efficiency in lowland rice in tropical Asia. Fert. Res. 9:171-186.

Fageria, N.K., Baligar, V.C. 2001. Lowland rice response to nitrogen fertilization. Commun. Soil Sci. Plant Anal. 32:1405-1429.

Fofana, M., Cherif, M., Kone, B., Futakuchi, K., Audebert, A. 2010. Effect of water deficit at grain ripening stage on rice grain quality. J. Agric. Biotec. and Sustain. Develop. 2:100-107.

Gomez, K.A., Gomez, A.A. 1984. Statistical Procedures for Agricultural Research.1st Edn. Wiley Inter Science Publication, John Wiley and Sons. New York, USA. 680 p.

Huang, D.F., Xi, L.L., Wang, Z.Q., Liu, L.J., Yang, J.C. 2008. Effects of irrigation regimes during grain filling on grain quality and the concentration and distribution of cadmium in different organs of rice. Acta Agronomica Sinica. 34:456-464.

Hao, H.-L., Wei, Y.-Z., Yang, X.-E., Feng, Y., Wu, C.-Y. 2007. Effects of different nitrogen fertilizer levels on $\mathrm{Fe}, \mathrm{Mn}, \mathrm{Cu}$ and $\mathrm{Zn}$ concentrations in shoot and grain quality in rice (Oryza sativa). Rice Sci. 14:289-294.

Jongkaewwattana, S., Geng, S., Brandon, D.M., Hill, J.E. 1993. Effect of nitrogen and harvest grain moisture on head rice yield. Agron. J. 85:1143-1146.

Juliano, B.O., Antonio, A.A., Esmama, B.V. 1973. Effect of protein content on the distribution and properties of rice protein. J. Sci. Food Agric. 24:295-306.

Kaur, J., Mahal, S.S. 2014. Irrigation scheduling for enhancing water productivity of direct seeded basmati rice (Oryza sativa L.). In: Proc. Nat. Symp. on Agricultural Diversification for Sustainable livelihood and Environmental Security. Ludhiana, Punjab, India. pp. 180-181.

Kavitha, M.P., Balasubramanian, R., Babu, R., Paul Pandi, V.K. 2008. Effect of nitrogen and potassium management on yield attributes, yield and quality parameters of hybrid rice. Crop Res. 35:172-175.

Leesawatwong, M., Jamjod, S., Kuo, J., Dell, B., Rerkasem, B. 2005. Nitrogen fertilizer increases seed protein and milling quality of rice. Cereal Chem. 82:588-593.

Low, N.H. 1994. Carbohydrate analysis. In: Nielsen, S.S. (ed.), Introduction to the Chemical Analysis of Foods. Jones and Barlett Publishers, London, UK. 142 p.

Mahajan, G., Chauhan, B.S., Gill, M.S. 2011. Optimal nitrogen fertilization timing and rate in dry-seeded rice in northwest India. Agron. J. 103:1676-1682.

Morris, V.J. 1990. Starch gelation and retrogradation. Trends in Food Sci. and Technol. 1:2-6.

Samonte, S., Wilson, L.T., McClung, A.M., Tarpley, L. 2001. Seasonal dynamics of non-structural carbohydrate in 15 diverse rice genotypes. Crop Sci. 41:902-909.

Singh, N., Kaur, L., Sodhi, N.S., Sekhon, K.S. 2005. Physicochemical, cooking and textural properties of milled rice from different Indian rice cultivars. Food Chem. 89:253-259.

Singh, N., Kaur, R., Sharma, N., Mahajan, G., Bharaj, T.S. 2012. Changes in yield and grain quality characteristics of irrigated rice (Oryza sativa) genotypes under aerobic conditions. Indian J. Agric. Sci. 82:589-595.

Singh, N., Pal, N., Mahajan, G., Singh, S., Shevkani, K. 2011. Rice grain and starch properties: Effects of nitrogen fertilizer application. Carb. Polymers 86:219-225.

Vidal, V., Pons, B., Brunnschweiler, J., Handschin, S., Rouau, X., Mestres, C. 2007. Cooking behaviour of rice in relation to kernel physicochemical properties. J. Agric. Food Chem. 55:336-346. 